\title{
Publisher Correction: Environmental fluctuations accelerate molecular evolution of thermal tolerance in a marine diatom
}

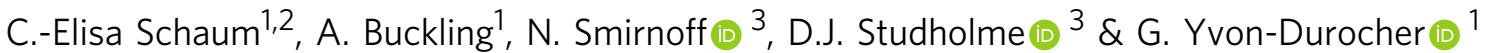

Correction to: Nature Communications; https://doi.org/10.1038/s41467-018-03906-5, published online: 30 April 2018

The PDF version of this Article was updated shortly after publication following an error which resulted in the $\Phi$ symbol being omitted from the left hand side of equation 8 . The HTML version was correct from the time of publication.

Published online: 13 July 2018

\begin{abstract}
(c) (i) Open Access This article is licensed under a Creative Commons Attribution 4.0 International License, which permits use, sharing, adaptation, distribution and reproduction in any medium or format, as long as you give appropriate credit to the original author(s) and the source, provide a link to the Creative Commons license, and indicate if changes were made. The images or other third party material in this article are included in the article's Creative Commons license, unless indicated otherwise in a credit line to the material. If material is not included in the article's Creative Commons license and your intended use is not permitted by statutory regulation or exceeds the permitted use, you will need to obtain permission directly from the copyright holder. To view a copy of this license, visit http://creativecommons.org/licenses/by/4.0/.
\end{abstract}

(c) The Author(s) 2018

\footnotetext{
${ }^{1}$ Environment and Sustainability Institute, University of Exeter, Penryn Campus, Penryn, Cornwall TR10 9EZ, UK. ${ }^{2}$ Institute for Hydrobiology and Fisheries, Section Oceanography, Hamburg University, 22767 Hamburg, Germany. ${ }^{3}$ Biosciences, College of Life and Environmental Sciences, Geoffrey Pope Building University of Exeter, Exeter EX4 4QD, UK. Correspondence and requests for materials should be addressed to C.-E.S. (email: elisa.schaum@uni-hamburg.de) or to G.Y-D. (email: g.yvon-durocher@exeter.ac.uk)
} 